\title{
The FTO, PNPLA3 and TM6SF2 Gene Polymorphisms and Genetic Predisposition to NAFLD in Yakut Population
}

\author{
Aleksandra T. Diakonova*; Khariton A. Kurtanov, PhD; \\ Nadezhda I. Pavlova, PhD; Tuyara N. Aleksandrova \\ Yakut Science Center of Complex Medical Problems \\ Yakutsk, the Republic of Sakha (Yakutia), Russia
}

\begin{abstract}
The aim of our research was to study the distribution of alleles and genotypes of the FTO rs9939609 SNP, the PNPLA3 rs738409 SNP, and the TM6SF2 rs58542926 SNP in the Yakut population.

Methods and Results: A total of 85 DNA samples from the population were tested. An analysis of the frequency distribution of alleles and genotypes of the FTO rs9939609 SNP in the study group did not reveal significant differences. An analysis of the frequency distribution of alleles and genotypes of the PNPLA3 rs738409 SNP revealed that in men and women the $\mathrm{G}$ allele and the homozygous GG genotype prevailed. The results of the analysis of the frequency distribution of alleles and genotypes of the TM6SF2 rs58542926 SNP showed the predominance of individuals with the C allele ( $89 \%$ in men and $90 \%$ in women) with statistical significance in women.

Conclusion: The further studies with a larger sample size are required to detect the features of the distribution of alleles and genotypes of the FTO rs9939609 SNP and the TM6SF2 rs58542926 SNP in that population. (International Journal of Biomedicine. 2021;11(1):92-95.)

Key Words: nonalcoholic fatty liver disease $\bullet$ single nucleotide polymorphism $\bullet$ genome-wide association study $\bullet$ Yakuts

For citation: Diakonova AT, Kurtanov KhA, Pavlova NI, Aleksandrova TN.The FTO, PNPLA3 and TM6SF2 Gene Polymorphisms and Genetic Predisposition to NAFLD in Yakut Population. International Journal of Biomedicine. 2021;11(1):92-95. doi:10.21103/ Article11(1)_OA16
\end{abstract}

\section{Abbreviations}

bp, base pairs; NAFLD, nonalcoholic fatty liver disease; PNPLA3, patatin-like phospholipase domain-containing protein 3; SNP, single nucleotide polymorphism; TM6SF2, transmembrane 6 superfamily member 2

\section{Introduction}

A person's genetic predisposition determines the risk of developing NAFLD. However, not all at-risk individuals develop the disease, suggesting that most complex multifactorial diseases are the result of interactions between genes and the environment. The onset or severity of the disease may differ in individuals with the same genotype in different environmental conditions, or vice versa, confirming that the phenotype is a consequence of genotype-environmental interactions; diet, lifestyle, exposure to chemicals and toxins

*Corresponding author: Aleksandra T. Diakonova. Yakut Science Center of Complex Medical Problems. Yakutsk, the Republic of Sakha (Yakutia), Russia.E-mail:dyakonovaa@bk.ru constitute the bulk of environmental risks. Most diseases of the modern lifestyle, such as diabetes, cardiovascular diseases, hypertension, and obesity, are usually transmitted by a multifactorial mode of inheritance. This term refers to a complex type of inheritance, which involves a combination of both genetic and other factors, including the environment. (1) Nonalcoholic fatty liver disease (NAFLD) is one of the most important complex and multifactorial lifestyle diseases. NAFLD initiates from extra fat storage in the liver and can advance to hepatitis, fibrosis, liver failure, and hepatocellular carcinoma. NAFLD is often associated with obesity, diabetes, and hyperlipidemia. The prevalence of the disease varies markedly in different populations. It ranges from $20 \%$ to $30 \%$ in Western countries, ${ }^{(2)}$ from $20 \%$ to $30 \%$ in Europeans, ${ }^{(3)}$ $8 \%$ to $9 \%$ in Japan, ${ }^{(4)}$ and $25 \%-30 \%$ in India. ${ }^{(5)}$ The overall 
prevalence of NAFLD in Asia has so far been estimated at $29.6 \%$. Due to significant changes in lifestyle and dietary habits, NAFLD has become a major social health burden in China, with a prevalence of $18.2 \%$ in $2000-2006,20.0 \%$ in 2007-2009, and $20.9 \%$ in 2010-2013. A recent meta-analysis found that the national prevalence of NAFLD in China reached $29.1 \%{ }^{(6)}$

Understanding genetic predisposition has been a major focus of recent research, in addition to changes in dietary habits and lifestyle modifications that have been shown to benefit patients with NAFLD and help better control the disease. (1) The GWAS identified several genes as a major genetic determinant for the predisposition to NAFLD. The association between SNPs in the fat mass and obesity-associated (FTO) gene and BMI and obesity has been confirmed in multiple populations. ${ }^{(7-13)}$ Gerken et al. ${ }^{(14)}$ showed that FTO shares sequence motifs with $\mathrm{Fe}(\mathrm{II})$ - and 2-oxoglutarate-dependent oxygenates, which allows it to alter DNA methylation and regulate gene transcription. The FTO gene encodes one of the lipolysis regulators, which is involved in the control of adipocyte differentiation, energy homeostasis, and leptinindependent appetite control. The FTO SNPs associated with adiposity are intronic and may exert functional effects through altered expression of FTO mRNA. According to the results of previous studies, the A allele of the FTO rs9939609 is associated with decreased lipolysis, impaired appetite control, and a lack of satiety after an adequate meal. ${ }^{(15-18)}$ The phenotypic manifestation of the A allele of the FTO gene is overweight and obesity due to overeating, ${ }^{(18,19)}$ which in turn is one of the most common risk factors for the development of NAFLD.

Molecular genetic studies have shown that the PNPLA3 gene, located on the long arm of chromosome 22q13.31, is expressed in the membranes of hepatocytes and is responsible for intrahepatic lipid metabolism by coding for the synthesis of adiponutrin, a protein that regulates the activity of triacylglycerolipase in adipocytes. The most significant polymorphism in the PNPLA3 gene is I148M (rs738409). The most prominent variant is the PNPLA3 rs 738409 [G], which is a nonsynonymous substitution of cytosine for guanine $(C>G)$ that changes codon 148 from encoding isoleucine (I) to methionine (M) (I>M, I148M). ${ }^{(20,21)}$ Wild-type (148I) PNPLA3 has lipolytic activity towards triglycerides. ${ }^{(22,23)}$ The $148 \mathrm{M}$ mutation leads to the development of macrovescicular steatosis. ${ }^{(22,23)}$ In humans, the PNPLA3 I148M mutation has been shown to influence not only intrahepatic remodeling but also reduces very low density lipoproteins (VLDL) secretion. ${ }^{(24)}$ Recently, a study showed that carriers of the rs738409[G] allele have lower de novo lipogenesis as compared to non-carriers due to a reduction in liver SREBP1c mRNA levels. ${ }^{(25)}$ However, the issue of the functional consequences of the I148M polymorphism is therefore still intensively debated. ${ }^{(26)}$

In 2014, the significance of rs58542926 in the transmembrane 6 superfamily member 2 (TM6SF2) gene in NAFLD was found for the first time. ${ }^{(27)}$ The TM6SF2 rs58542926 is a substitution of guanine by adenine in nucleotide 499, which leads to the replacement of glutamic acid by lysine in amino acid residue 167(E167K). ${ }^{(27)}$ Recent studies have found that TM6SF2 rs58542926 was a significant risk factor for the development of NAFLD. ${ }^{(28,29)}$

The aim of our research was to study the distribution of alleles and genotypes of the FTO rs9939609 SNP, the PNPLA3 rs738409 SNP, and the TM6SF2 rs58542926 SNP in the Yakut population.

\section{Materials and Methods}

The study of the FTO rs9939609, SNP the PNPLA3 rs738409 SNP, and the TM6SF2 rs58542926 SNP was carried out in the Department of Molecular Genetics at YSC CMP. For the study, we used DNA samples from the collection of biomaterials of the YSC KP using the UNU "Genome of Yakutia” (reg. No. USU_507512). A total of 85 DNA samples from the population were tested.

The inclusion criteria for the study were Yakuts by ethnicity, living in Yakutia, without liver damage by chronic viral hepatitis. Exclusion criteria: autoimmune hepatitis, primary biliary cholangitis, primary sclerosing cholangitis, hereditary hemochromatosis, Wilson-Konovalov disease, and alcohol abuse $(>30 \mathrm{~g} / \mathrm{l})$.

Genomic DNA samples were isolated from peripheral blood lymphocytes using a commercial DNA kit, Excel Biotech (Yakutsk). The study SNPs were analyzed by PCRRFLP reaction. The gene regions containing the polymorphic variants were amplified with standard pairs of primers produced by Biotech-Industry LLC (Moscow, Russia). The reaction mixture $(25 \mu \mathrm{l})$ for PCR contained of forward and reverse primer $(10 \mathrm{pmol} / \mu \mathrm{l})(1 \mu \mathrm{l})$ (Moscow, Russia), Dream Taq PCR master mix $(12.5 \mu \mathrm{l})$, deionized water $(9.5 \mu \mathrm{l})$, and DNA in the amount of $100 \mu \mathrm{g} / \mathrm{ml}(1 \mu \mathrm{l})$. A mixture for RFLP $(20 \mu \mathrm{L})$ consisted of amplificate $(7 \mu \mathrm{L})$, deionized water $(10.9 \mu \mathrm{L})$, restriction buffer $(2 \mu \mathrm{L})$, and restriction endunuclease Hpy $188 \mathrm{I}$ (2 u.a.) for the TM6SF2 gene, Zrm I (2 u.a.) for the gene FTO, and BstF5VI (2 e.a.) for the PNPLA3 gene.

The temperature-time regime for PCR is optimized for amplification of this nucleotide sequence and is presented in Table 1 .

Table 1.

Conditions for PCR

\begin{tabular}{|c|c|c|c|}
\hline Gene & Amplification & $\begin{array}{l}\text { The length of the } \\
\text { restriction fragments }\end{array}$ & PCR conditions \\
\hline$T M 6 S F 2$ & $429 \mathrm{bp}$ & $\begin{array}{l}\text { CC-178 bp, } 166 \text { bp, } \\
85 \text { bp } \\
\text { TT-251, } 178 \text { bp } \\
\text { CT-251 bp, } 178 \text { bp, } \\
166 \text { bp, } 85 \text { bp }\end{array}$ & $\begin{array}{l}1.94{ }^{\circ} \mathrm{C}-10 \mathrm{~min} \\
2 .\left(94^{\circ} \mathrm{C}-1 \mathrm{~min} ;\right. \\
62{ }^{\circ} \mathrm{C}-40 \mathrm{sec} ; 72{ }^{\circ} \mathrm{C} \\
-1 \mathrm{~min})-40 \text { cycles } \\
3.72{ }^{\circ} \mathrm{C}-10 \mathrm{~min}\end{array}$ \\
\hline FTO & $182 \mathrm{bp}$ & $\begin{array}{l}\text { AA-154 bp, } 28 \text { bp } \\
\text { AT-154 bp, } 28 \text { bp, } \\
182 \text { bp } \\
\text { TT-182 bp }\end{array}$ & $\begin{array}{l}\text { 1. } 95^{\circ} \mathrm{C}-4 \mathrm{~min} \\
2 .\left(94{ }^{\circ} \mathrm{C}-30 \mathrm{sec} ;\right. \\
58^{\circ} \mathrm{C}-30 \mathrm{sec} ; 72^{\circ} \mathrm{C} \\
-1 \mathrm{~min})-35 \mathrm{cycles} \\
3.72^{\circ} \mathrm{C}-10 \mathrm{~min}\end{array}$ \\
\hline PNPLA3 & $333 \mathrm{bp}$ & $\begin{array}{l}\text { CC-200 bp, } 133 b p \\
\text { GC-333 bp, } 200 b p \\
133 \text { bp } \\
\text { GG-333 bp }\end{array}$ & $\begin{array}{l}1.95^{\circ} \mathrm{C}-5 \mathrm{~min} \\
2 .\left(94^{\circ} \mathrm{C}-30 \mathrm{sec} ;\right. \\
66^{\circ} \mathrm{C}-30 \mathrm{sec} ; 72{ }^{\circ} \mathrm{C} \\
-40 \mathrm{sec}-37 \mathrm{cycles} \\
3.72^{\circ} \mathrm{C}-5 \mathrm{~min}\end{array}$ \\
\hline
\end{tabular}


PCR products were detected by horizontal electrophoresis in a $2 \%$ agarose gel plate with the addition of ethidium bromide, a specific intercalating fluorescent DNA (RNA) dye, using a standard Tris-acetate buffer at a field voltage of $\sim 20 \mathrm{~V} / \mathrm{cm}$ for 30 minutes. RFLP products were detected by horizontal electrophoresis in $4 \%$ agarose gel stained with ethidium bromide using a standard Tris-acetate buffer at $120 \mathrm{~V}$ for 1 hour.

Statistical analysis was performed using the Statistica 8.0 software package (Stat-Soft Inc., USA). The correspondence of the distributions of genotypes to the expected values at HWE and comparison of the frequencies of allelic variants/genotypes were performed using the chi-square test. A probability value of $\mathrm{P}<0.05$ was considered statistically significant.

\section{Results and Discussion}

An analysis of the frequency distribution of alleles and genotypes of the FTO rs9939609 SNP in the study group did not reveal significant differences (Table 2). An analysis of the frequency distribution of alleles and genotypes of the PNPLA3 rs738409 SNP revealed that in men and women the G allele and the homozygous GG genotype prevailed (Table 3). The results of the analysis of the frequency distribution of alleles and genotypes of the TM6SF2 rs58542926 SNP showed the predominance of individuals with the $\mathrm{C}$ allele ( $89 \%$ in men and $90 \%$ in women) with statistical significance in women (Table 4).

Table 2.

Frequency distribution of alleles and genotypes of the FTO rs9939609 SNP in the study group

\begin{tabular}{|c|c|c|c|c|c|c|c|c|c|}
\hline \multirow{2}{*}{ FTO } & \multirow{2}{*}{$\mathrm{n}$} & & \multicolumn{3}{|c|}{ Genotype, \% } & \multicolumn{2}{|c|}{ Allele, \% } & \multirow{2}{*}{$\chi^{2}$} & \multirow{2}{*}{$P$} \\
\hline & & & $\mathrm{AA}$ & AT & TT & A & $\mathrm{T}$ & & \\
\hline \multirow{2}{*}{ All } & \multirow{2}{*}{85} & $\mathrm{O}$ & 4 & 30 & 66 & \multirow{2}{*}{19} & \multirow{2}{*}{81} & \multirow{2}{*}{0.012} & \multirow{2}{*}{0.912} \\
\hline & & $\mathrm{E}$ & 4 & 30,5 & 65,5 & & & & \\
\hline \multirow{2}{*}{ Woman } & \multirow{2}{*}{63} & $\mathrm{E}$ & 13 & 27 & 60 & \multirow{2}{*}{26} & \multirow{2}{*}{74} & \multirow{2}{*}{5.748} & \multirow{2}{*}{0.0165} \\
\hline & & $\mathrm{E}$ & 7 & 39 & 54 & & & & \\
\hline \multirow{2}{*}{ Man } & \multirow{2}{*}{22} & $\mathrm{O}$ & 4 & 32 & 64 & \multirow{2}{*}{20} & \multirow{2}{*}{80} & \multirow{2}{*}{0.011} & \multirow{2}{*}{0.917} \\
\hline & & E & 4 & 32 & 64 & & & & \\
\hline
\end{tabular}

Note: $O$ - observed; $E$ - expected.

Table 3.

Frequency distribution of alleles and genotypes of the PNPLA3 rs 738409 SNP in the study group

\begin{tabular}{|c|c|c|c|c|c|c|c|c|c|}
\hline \multirow{2}{*}{ PNPLA3 } & \multirow{2}{*}{$\mathrm{n}$} & & \multicolumn{3}{|c|}{ Genotype, \% } & \multicolumn{2}{|c|}{ Allele, $\%$} & \multirow{2}{*}{$\chi^{2}$} & \multirow{2}{*}{$P$} \\
\hline & & & $\mathrm{CC}$ & $\mathrm{CG}$ & GG & $\mathrm{C}$ & G & & \\
\hline \multirow{2}{*}{ All } & \multirow{2}{*}{85} & $\mathrm{O}$ & 14 & 33 & 53 & \multirow{2}{*}{31} & \multirow{2}{*}{69} & \multirow{2}{*}{4.274} & \multirow{2}{*}{0.0387} \\
\hline & & $\mathrm{E}$ & 9 & 43 & 48 & & & & \\
\hline \multirow{2}{*}{ Woman } & \multirow{2}{*}{63} & $\mathrm{O}$ & 13 & 32 & 55 & \multirow{2}{*}{29} & \multirow{2}{*}{71} & \multirow{2}{*}{3.11} & \multirow{2}{*}{0.0778} \\
\hline & & $\mathrm{E}$ & 8 & 41 & 51 & & & & \\
\hline \multirow{2}{*}{ Man } & \multirow{2}{*}{22} & $\mathrm{O}$ & 18 & 36 & 45 & \multirow{2}{*}{36} & \multirow{2}{*}{64} & \multirow{2}{*}{1.01} & \multirow{2}{*}{0.3149} \\
\hline & & E & 13 & 46 & 40 & & & & \\
\hline
\end{tabular}

The frequency of occurrence of the mutant alleles of the study SNPs in various populations, according to Ensembl.org, is presented in Table 5 .
Table 4.

Frequency distribution of alleles and genotypes of the TM6SF2 rs58542926 SNP in the study group

\begin{tabular}{|c|c|c|c|c|c|c|c|c|c|}
\hline \multirow{2}{*}{ TM6SF2 } & \multirow{2}{*}{$\mathrm{n}$} & & \multicolumn{3}{|c|}{ Genotype, \% } & \multicolumn{2}{|c|}{ Allele, $\%$} & \multirow{2}{*}{$\chi^{2}$} & \multirow{2}{*}{$P$} \\
\hline & & & $\mathrm{CC}$ & $\mathrm{CT}$ & TT & $\mathrm{C}$ & $\mathrm{T}$ & & \\
\hline \multirow{2}{*}{ All } & \multirow{2}{*}{85} & $\mathrm{O}$ & 84 & 12 & 4 & \multirow{2}{*}{89} & \multirow{2}{*}{11} & \multirow{2}{*}{12.187} & \multirow{2}{*}{0.0005} \\
\hline & & $E$ & 80 & 19 & 1 & & & & \\
\hline \multirow{2}{*}{ Woman } & \multirow{2}{*}{63} & $\mathrm{O}$ & 84 & 11 & 5 & \multirow{2}{*}{90} & \multirow{2}{*}{10} & \multirow{2}{*}{10.059} & \multirow{2}{*}{0.0015} \\
\hline & & $\mathrm{E}$ & 80 & 18 & 1 & & & & \\
\hline \multirow{2}{*}{ Man } & \multirow{2}{*}{22} & $\mathrm{O}$ & 82 & 14 & 4 & \multirow{2}{*}{89} & \multirow{2}{*}{11} & \multirow{2}{*}{2.296} & \multirow{2}{*}{0.1297} \\
\hline & & $\mathrm{E}$ & 79 & 20 & 1 & & & & \\
\hline
\end{tabular}

Table 5.

The frequency of occurrence of the mutant alleles (\%) of the study SNPs in various populations, according to Ensembl.org

\begin{tabular}{|l|c|c|c|c|c|c|}
\hline \multicolumn{1}{|c|}{ SNP } & $\begin{array}{c}\text { Mutant } \\
\text { allele }\end{array}$ & Yakuts & $\begin{array}{c}\text { Puerto } \\
\text { Ricans }\end{array}$ & Peruvians & Finns & $\begin{array}{c}\text { South Han } \\
\text { Chinese }\end{array}$ \\
\hline $\begin{array}{l}\text { rs9939609 } \\
\text { FTO }\end{array}$ & A & 19 & 36 & 8 & 39 & 14 \\
\hline $\begin{array}{l}\text { rs738409 } \\
\text { PNPLA3 }\end{array}$ & G & 69 & 32 & 72 & 17 & 38 \\
\hline $\begin{array}{l}\text { rs58542926 } \\
\text { TM6SF2 }\end{array}$ & T & 11 & 9 & 5 & 6 & 11 \\
\hline
\end{tabular}

We previously found a high frequency of the PNPLA3 (rs738409) [G] allele in the Yakut population (72\%-73\%). ${ }^{(30,31)}$ The accumulation of triglycerides in hepatocytes, associated with the PNPLA3 p.I148M variant, was probably an adaptation to a cold climate; this accumulation is not needed in the modern world, but leads to NAFLD among the Yakut population. As noted by many domestic and foreign researchers, carriers of the PNPLA3 G allele are more susceptible to liver diseases (NAFLD, NASH) with a high risk of developing cirrhosis and hepatocellular carcinoma. ${ }^{(20)}$

Undoubtedly, further studies with a larger sample size are required to detect the features of the distribution of alleles and genotypes of the FTO rs9939609 SNP and the TM6SF2 rs58542926 SNP in that population.

\section{Competing Interests}

The authors declare that they have no competing interests.

\section{References}

1. Kumar A, Shalimar, Walia GK, Gupta V, Sachdeva MP. Genetics of nonalcoholic fatty liver disease in Asian populations. J Genet. 2019 Mar;98:29. PMID: 30945694.

2. Bellentani S, Scaglioni F, Marino M, Bedogni G. Epidemiology of non-alcoholic fatty liver disease. Dig Dis. 2010;28(1):155-61. doi: 10.1159/000282080.

3. Blachier M, Leleu H, Peck-Radosavljevic M, Valla DC, Roudot-Thoraval F. The burden of liver disease in Europe: a review of available epidemiological data. J Hepatol. 2013 Mar;58(3):593-608. doi: 10.1016/j.jhep.2012.12.005.

4. Kawaguchi T, Sumida Y, Umemura A, Matsuo K, Takahashi M, Takamura T, et al.; Japan Study Group of Nonalcoholic Fatty Liver Disease. Genetic polymorphisms of 
the human PNPLA3 gene are strongly associated with severity of non-alcoholic fatty liver disease in Japanese. PLoS One. 2012;7(6):e38322. doi: 10.1371/journal.pone.0038322.

5. Amarapurkar D, Kamani P, Patel N, Gupte P, Kumar P, Agal S, et al. Prevalence of non-alcoholic fatty liver disease: population based study. Ann Hepatol. 2007 Jul-Sep;6(3):161-3. 6. Gu Z, Bi Y, Yuan F, Wang R, Li D, Wang J, et al. FTO Polymorphisms are Associated with Metabolic Dysfunction-Associated Fatty Liver Disease (MAFLD) Susceptibility in the Older Chinese Han Population. Clin Interv Aging. 2020 Aug 11;15:1333-1341. doi: 10.2147/CIA.S254740.

7. Scuteri A, Sanna S, Chen WM, Uda M, Albai G, Strait J, et al. Genome-wide association scan shows genetic variants in the FTO gene are associated with obesity-related traits. PLoS Genet. 20071;3(7):e115. doi: 10.1371/journal.pgen.0030115.

8. Andreasen $\mathrm{CH}$, Stender-Petersen KL, Mogensen MS, Torekov SS, Wegner L, Andersen G, et al. Low physical activity accentuates the effect of the FTO rs9939609 polymorphism on body fat accumulation. Diabetes. 2008 Jan;57(1):95-101. doi: 10.2337/db07-0910.

9. Do R, Bailey SD, Desbiens K, Belisle A, Montpetit A, Bouchard C, et al. Genetic variants of FTO influence adiposity, insulin sensitivity, leptin levels, and resting metabolic rate in the Quebec Family Study. Diabetes. 2008 Apr;57(4):1147-50. doi: $10.2337 / \mathrm{db} 07-1267$.

10. Grant SF, Li M, Bradfield JP, Kim CE, Annaiah K, Santa E, et al. Association analysis of the FTO gene with obesity in children of Caucasian and African ancestry reveals a common tagging SNP. PLoS One. 2008;3(3):e1746. doi: 10.1371/journal. pone.0001746.

11. Hinney A, Nguyen TT, Scherag A, Friedel S, Brönner G, Müller TD, et al. Genome wide association (GWA) study for early onset extreme obesity supports the role of fat mass and obesity associated gene (FTO) variants. PLoS One. 2007 Dec 26;2(12):e1361. doi: 10.1371/journal.pone.0001361.

12. Hubacek JA, Bohuslavova R, Kuthanova L, Kubinova R, Peasey A, Pikhart H, Marmot MG, Bobak M. The FTO gene and obesity in a large Eastern European population sample: the HAPIEE study. Obesity (Silver Spring). 2008 Dec;16(12):2764-6. doi: 10.1038/oby.2008.421.

13. Hunt SC, Stone S, Xin Y, Scherer CA, Magness CL, Iadonato SP, Hopkins PN, Adams TD. Association of the FTO gene with BMI. Obesity (Silver Spring). 2008 Apr;16(4):9024. doi: 10.1038/oby.2007.126.

14. Gerken T, Girard CA, Tung YC, Webby CJ, Saudek V, Hewitson KS, et al. The obesity-associated FTO gene encodes a 2-oxoglutarate-dependent nucleic acid demethylase. Science. 2007;318(5855):1469-72. doi: 10.1126/science.1151710.

15. Speakman JR, Rance KA, Johnstone AM. Polymorphisms of the FTO gene are associated with variation in energy intake, but not energy expenditure. Obesity (Silver Spring). 2008 Aug;16(8):1961-5. doi: 10.1038/oby.2008.318.

16. Wardle J, Llewellyn C, Sanderson S, Plomin R. The FTO gene and measured food intake in children. Int J Obes (Lond). 2009 Jan;33(1):42-5. doi: 10.1038/ijo.2008.174.

17. den Hoed M, Westerterp-Plantenga MS, Bouwman FG, Mariman EC, Westerterp KR. Postprandial responses in hunger and satiety are associated with the rs9939609 single nucleotide polymorphism in FTO. Am J Clin Nutr. 2009 Nov;90(5):1426-32. doi: 10.3945/ajen.2009.28053.

18. Tanofsky-Kraff M, Han JC, Anandalingam K, Shomaker LB, Columbo KM, Wolkoff LE, et al. The FTO gene rs9939609 obesity-risk allele and loss of control over eating. Am J Clin Nutr. 2009 Dec;90(6):1483-8. doi: 10.3945/ajcn.2009.28439. 19. Cecil JE, Tavendale R, Watt P, Hetherington MM, Palmer CN. An obesity-associated FTO gene variant and increased energy intake in children. N Engl J Med. 2008 Dec 11;359(24):2558-66. doi: 10.1056/NEJMoa0803839.

20. Romeo S, Kozlitina J, Xing C, Pertsemlidis A, Cox D, Pennacchio LA, et al. Genetic variation in PNPLA3 confers susceptibility to nonalcoholic fatty liver disease. Nat Genet. 2008 Dec;40(12):1461-5. doi: 10.1038/ng.257.

21. Xu R, Tao A, Zhang S, Deng Y, Chen G. Association between patatin-like phospholipase domain containing 3 gene (PNPLA3) polymorphisms and nonalcoholic fatty liver disease: a HuGE review and meta-analysis. Sci Rep. 2015 Mar 20;5:9284. doi: 10.1038/srep09284.

22. He S, McPhaul C, Li JZ, Garuti R, Kinch L, Grishin NV, Cohen JC, Hobbs HH. A sequence variation (I148M) in PNPLA3 associated with nonalcoholic fatty liver disease disrupts triglyceride hydrolysis. J Biol Chem. 2010 Feb 26;285(9):6706-15. doi: 10.1074/jbc.M109.064501.

23. Pirazzi C, Adiels M, Burza MA, Mancina RM, Levin M, Ståhlman M, et al. Patatin-like phospholipase domaincontaining 3 (PNPLA3) I148M (rs738409) affects hepatic VLDL secretion in humans and in vitro. J Hepatol. 2012 Dec;57(6):1276-82. doi: 10.1016/j.jhep.2012.07.030.

24. Petit JM, Guiu B, Masson D, Duvillard L, Jooste V, Buffier P, et al. Specifically PNPLA3-mediated accumulation of liver fat in obese patients with type 2 diabetes. J Clin Endocrinol Metab. 2010 Dec;95(12):E430-6. doi: 10.1210/jc.2010-0814. 25. Cox AJ, Wing MR, Carr JJ, Hightower RC, Smith SC, Xu J, et al. Association of PNPLA3 SNP rs738409 with liver density in African Americans with type 2 diabetes mellitus. Diabetes Metab. 2011;37(5):452-5. doi: 10.1016/j.diabet.2011.05.001.

26. Dongiovanni P, Donati B, Fares R, Lombardi R, Mancina RM, Romeo S, Valenti L. PNPLA3 I148M polymorphism and progressive liver disease. World J Gastroenterol. 2013 Nov 7;19(41):6969-78. doi: 10.3748/wjg.v19.i41.6969.

27. Kozlitina J, Smagris E, Stender S, Nordestgaard BG, Zhou HH, Tybjærg-Hansen A, et al. Exome-wide association study identifies a TM6SF2 variant that confers susceptibility to nonalcoholic fatty liver disease. Nat Genet. 2014 Apr;46(4):352-6. doi: 10.1038/ng.2901.

28. Chen LZ, Xia HH, Xin YN, Lin ZH, Xuan SY. TM6SF2 E167K Variant, a Novel Genetic Susceptibility Variant, Contributing to Nonalcoholic Fatty Liver Disease. J Clin Transl Hepatol. 2015;3(4):265-70. doi: 10.14218/JCTH.2015.00023. 29. Li Y, Liu S, Gao Y, Ma H, Zhan S, Yang Y, Xin Y, Xuan S. Association of TM6SF2 rs58542926 gene polymorphism with the risk of non-alcoholic fatty liver disease and colorectal adenoma in Chinese Han population. BMC Biochem. 2019 Feb 6;20(1):3. doi: 10.1186/s12858-019-0106-3.

30. Kurtanov KA, Sydykova LA, Pavlova NI, Filippova NP, Dodokhov VV, Apsolikhova GA, et al. [Polymorphism of the adiponutrin gene (PNPLA3) in the indigenous inhabitants of the Republic of Sakha (Yakutia) with type 2 diabetes mellitus]. Almanac of Clinical Medicine. 2018;46(3):258-263. doi: 10.18786/2072-0505-2018-46-3-258-263. [Article in Russian]. 31. Kurtanov KA, Pavlova NI, Diakonova AT, Sydykova LA, Aleksandrova TN, Borisova YP, Dodokhov VV. The structure of Haplotypes and Diplotypes in the PNPLA3 gene in the Yakut Population International Journal of Biomedicine. 2020; 10(4):433-437. 